\title{
Virtual Water and Its Share in Per-capita Water Availability (Case Study of Ethiopia)
}

\section{Dereje Adeba, Gedefa Lelisa}

Department of Hydraulic and Water Resources Engineering, College of Engineering and Technology, Wollega University, Nekemte, Ethiopia

\section{Email address:}

mo_dereje2018@yahoo.com (D. Adeba),gedefalelisa@gmail.com (G. Lelisa)

\section{To cite this article:}

Dereje Adeba, Gedefa Lelisa. Virtual Water and Its Share in Per-capita Water Availability (Case Study of Ethiopia). Hydrology.

Vol. 9, No. 2, 2021, pp. 21-35. doi: 10.11648/j.hyd.20210902.11

Received: February 22, 2021; Accepted: April 21, 2021; Published: May 8, 2021

\begin{abstract}
Today, the security, stability and environmental sustainability of developing nations are threatened by the growing global water crisis. This crisis is partly due to water governance. Improving water infrastructure must be a priority, as water conservation and efficiency are key components of sustainable water management. The idea of virtual water import/export as a method to ease the pressure on the available domestic water resources is a concern for sustainable water management. This concept of virtual water further extends the scope of water resources management beyond the boundary of natural watershed. Since the water use of a given watershed can be influenced by water use outside of the watershed through virtual water transfers, it is not sufficient to confine the water resources management to the basin or catchment scale. The role of virtual water in bridging the gap between supply and demand of water is underestimated. Although invisible, the importance of 'virtual water' can be an effective means for water-scarce countries to preserve their domestic water resources. This paper examines the virtual water concepts in relation to per capita water availability taking 2000 to 2015 years as the period of analysis. The results of the study showed that the total exported and imported virtual water in the period of analysis in Ethiopia is 113 billion $\mathrm{m}^{3}$ and 10.9 billion $\mathrm{m}^{3}$ respectively. These values showed that Ethiopia is a net virtual water exporter. The maximum and minimum per-capita water availability during the analysis period was $2590 \mathrm{~m}^{3} / \mathrm{cap} /$ year and $1740 \mathrm{~m}^{3} /$ cap/year respectively. These results indicated no water stress in the period of analysis.
\end{abstract}

Keywords: Global Water Crisis, Virtual Water, Environmental Sustainability, Export and Imported Commodities

\section{Introduction}

\subsection{Description of the Study Area}

Ethiopia is a landlocked country located between $33^{\circ}$ to $48^{\circ} \mathrm{E}$ longitude and $3^{\circ}$ to $15^{\circ} \mathrm{N}$ latitude. Ethiopia has a geographical area of 1.104. Million $\mathrm{km}^{2}$ [1]. It is a land of great geographical diversity: topographic features ranging from the lowest depression (Dalol) at $116 \mathrm{~m}$ below msl to the highest peak (Ras Dashen) at 4,620m above sea level. The climatic conditions of the country are elevation (altitude) dependent, with temperature as high as $47^{\circ} \mathrm{C}$ in Denakil depression and as low as $10^{\circ} \mathrm{C}$ in the highlands [2]. The total population of the country is $108,925,111$ [1]. The country is located within the tropics, and its physical characteristics and variations in altitude have resulted in the great diversity of terrain, climate, soil, flora, and fauna. Figure 1 below shows the location map of Ethiopia in the horn of Africa.

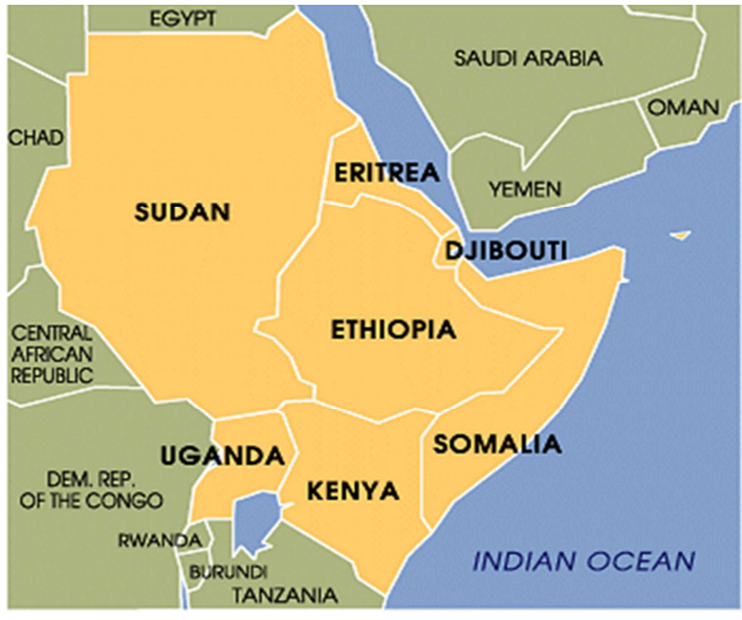

Figure 1. Location map of Ethiopia. 


\subsection{Ethiopia's Water Resources Potential}

Ethiopia receives an average of $850 \mathrm{~mm}$ rainfall per year, or the equivalent of $940 \mathrm{~km}^{3}$ per year [3]. Approximately $13 \%$ of total rainfall is diverted into so-called blue water, i.e. river flows and freshwater in lakes. Most rainfall is allocated to green flows, i.e. water transpired and evaporated from different land-use systems. Of total rainfall, only $3 \%$ can be allocated to rain-fed agricultural production, which occupies $15 \%$ of the Ethiopia land mass [2].

Ethiopia's rainfall shows high spatial and temporal variability. The highest mean annual rainfall (more than 2,700 millimeters) occurs in the southwestern highlands, and then it gradually decreases in the north (to less than 200 millimeters), northeast (to less than 100 millimeters), and southeast (to less than 200 millimeters) [3].

Based on the annual rainfall distribution patterns, three major rainfall regimes can be identified: The southwestern and western areas of the country which are characterized by a single peak rainfall pattern. Figures 2, 3, 4 show mean monthly rainfall distributions of different parts of Ethiopia.

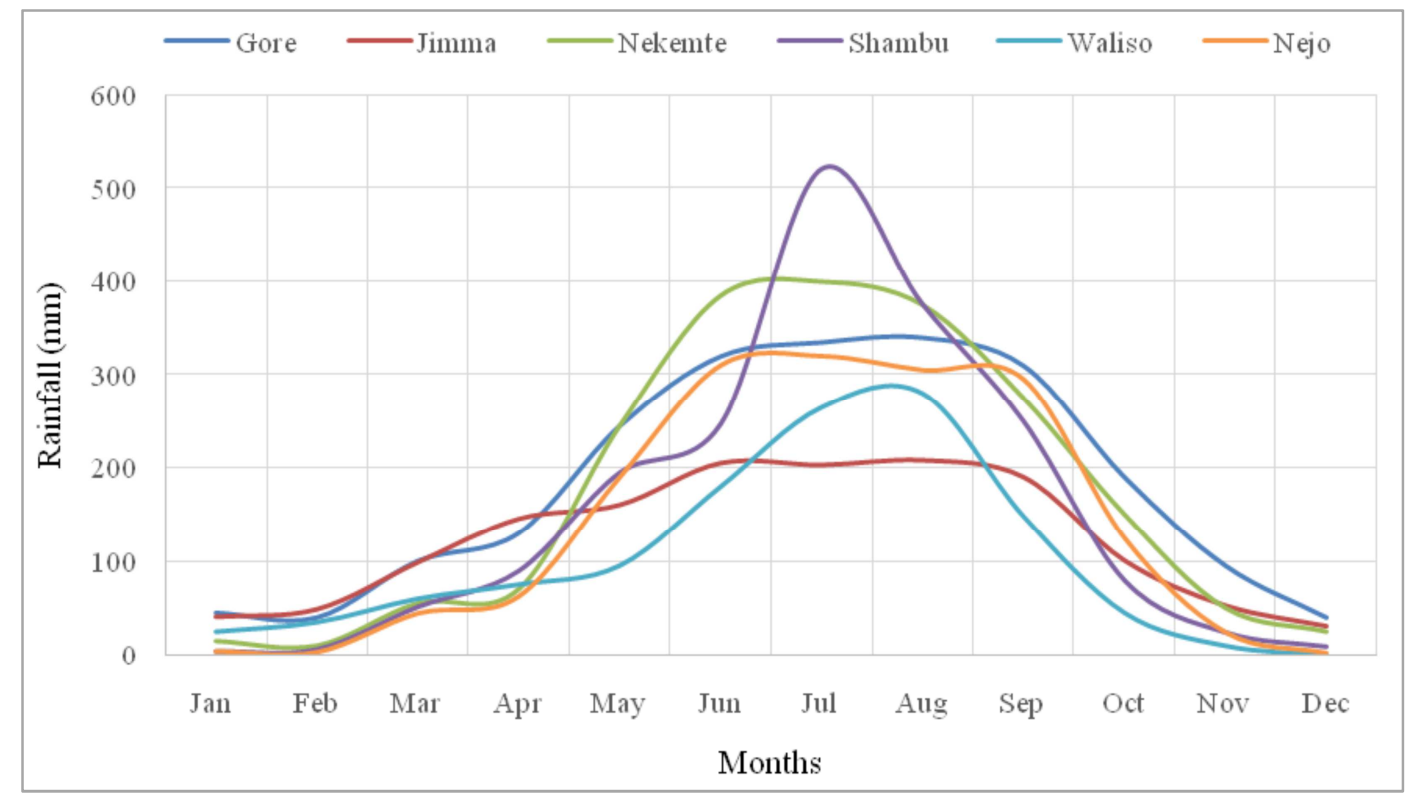

Figure 2. Mean monthly rainfall distribution of different stations for western Ethiopia.

The central, eastern, and northeastern areas of the country experience a nearly two peak rainfall distribution; the two rainy seasons are called arfasaa (smaller rains from February to May) and ganna (big rains from June to September).

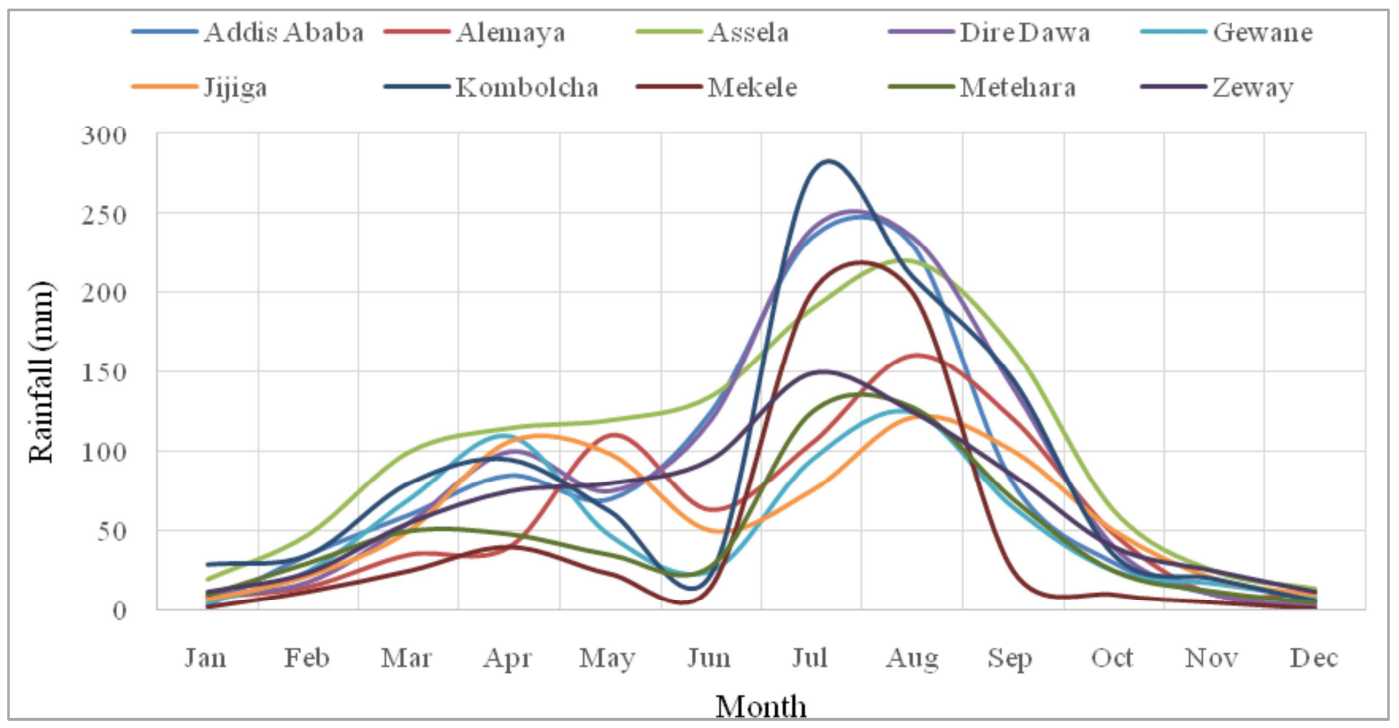

Figure 3. Mean monthly rainfall distributions of different stations for central and eastern Ethiopia.

The southern and southeastern areas of the country are dominated by a distinctly two peak rainfall pattern; the rainy seasons are September to November and March to May, with two distinct dry periods separating them. 


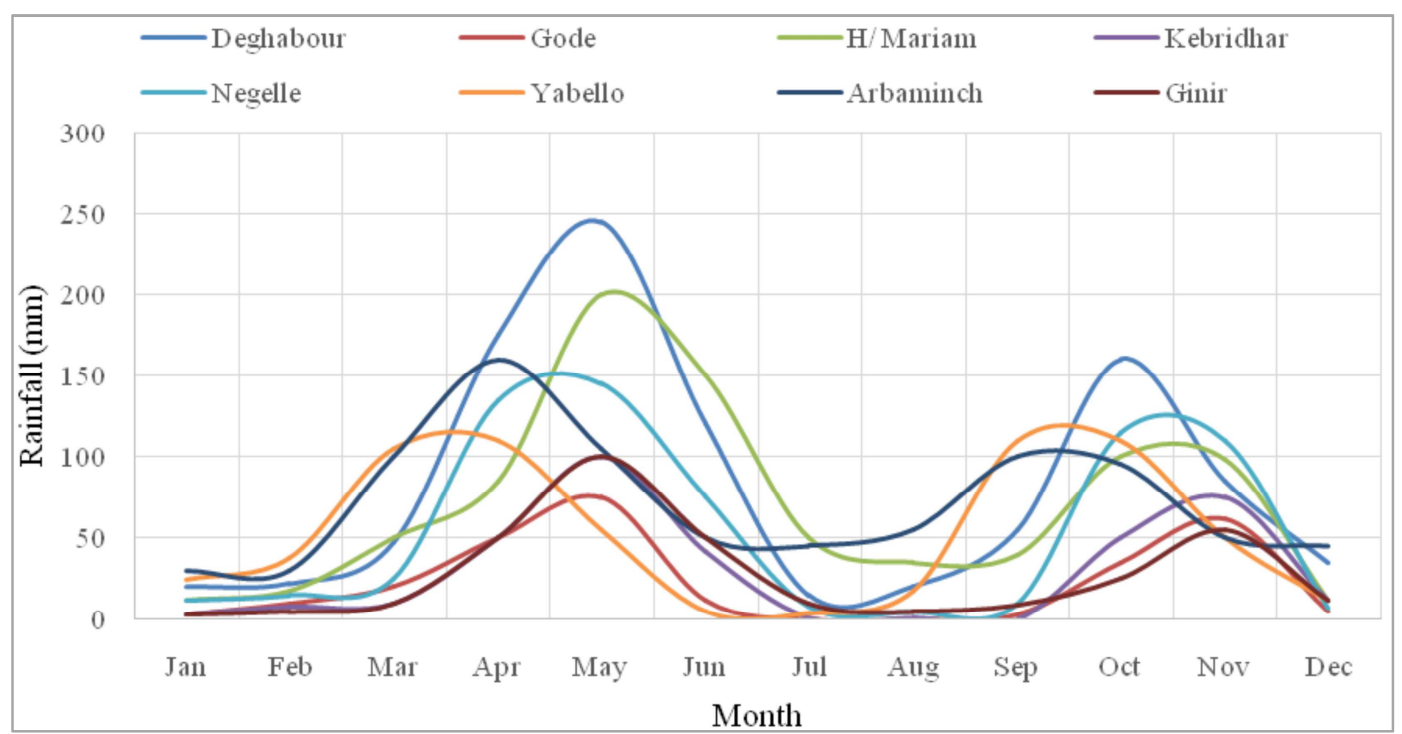

Figure 4. Mean Monthly rainfall distributions of different stations for southern and south-eastern Ethiopia.

Ethiopia has 12 major river basins, with a total estimated annual flow of 122 billion $\mathrm{m}^{3}$ of surface water and 40 billion $\mathrm{m}^{3}$ of groundwater. The total water resources potential of the country is estimated at 162 billion $\mathrm{m}^{3}$ [3]. Most of the river basins are transboundary and $97 \%$ of the total estimated basins annual discharge flows to the adjoining countries while the remaining $3 \%$ remain within the country $[4,5]$. As a result of this, Ethiopia is the main source of freshwater and large amounts of weathered alluvial soil to its neighboring countries and northeast Africa.

The Ethiopian highlands contribute to three major river systems, the Nile, Awash, and Omo [6]. The northern and central highlands drain westward into Ethiopia's largest river system, the Abbay, or Blue Nile, into the Tekeze River, a tributary of the main Nile, and the Baro River, a tributary of the White Nile. The eastern highlands drain into the Awash River, which never reaches the sea, but is ultimately absorbed into a succession of lakes and marshes near the Djibouti border. In the south, the Omo River drains into Lake Turkana, and several streams flow into the other Rift Valley lakes. In the southeast, the mountains of Arsi, Bale, and Sidamo drain toward Somalia and the Indian Ocean, but only the Genale or Juba River permanently flows into the sea. Apart from the larger rivers, there are few perennial streams below 1,000 meters [7].

Groundwater is an important source of raw water for urban and rural domestic supplies, and although the country's complex geology does not lend itself to major groundwater developments, there is also potential to develop smaller aquifers for irrigation and water supply and to explore opportunities for artificial recharge. There is limited information on Ethiopia's renewable groundwater resources, which are estimated at 40 billion cubic meters, although the Ethiopian Geological Survey is currently conducting groundwater investigations.

There are 11 major freshwater lakes, 9 saline lakes and over 12 major wetland areas in the country [8]. Lake Tana, with an area of 3,600 square kilometers, is the largest of 15 natural lakes in Ethiopia, with a total surface area of about 6,900 square kilometers. Seven of the eight major natural lakes are found in the Rift Valley. Most Ethiopian lakes except Zeway, Tana, Langano, Abaya, and Chamo are terminal lakes. Lakes Shala and Abayata have concentrations of chemicals used in the production of soda ash.

As pressures on water resources intensify globally, there is growing interest in evaluating the complex ways in which day to day human activities impact the world's water resources [9].

Traditionally, water has been thought of as a local or regional resource, but as globalization came into picture, it has an increasing interconnectedness among people and an economy. So better understanding of virtual water is needed to know its impacts on per capita water availability on global scale if possible, if not on a country basis. In recent years, there has been an explosion of interest in developing the methods and data necessary for evaluating and comparing water footprints. The water footprint of a country is the volume of water needed for the assembly of the products and services consumed by the inhabitants of the country. The water footprint of a nation can be assessed by taking the utilization of domestic water resources, minus the virtual water flow that leaves the country plus the virtual water flow that enters the country [10]. Virtual water is the volume of water required to produce a commodity or service. The total water footprint of a product can be broken down into three components: the blue, green and grey water footprint [11]. The blue water footprint is the volume of freshwater that is evaporated worldwide. Blue water resources (surface water and groundwater) that is used to produce the goods and services consumed by the individual or the community. The green water footprint is the volume of water evaporated from the global green water resources (rainwater kept within the soil as soil moisture). The grey water footprint is the volume of impure water that associates with the production of all 
goods and services for the individual or community. The water footprint of a nation has two elements. The internal water footprint, water used within the country to produce goods and services consumed by the national population. The external water footprint of a country, the annual volume of water resources employed in different countries to produce goods and services imported into and consumed in the country considered [12].

\section{Materials and Methods}

In this paper, we quantify the virtual water trade flows between nations and the associated water savings with 2001 as the baseline year and projected to 2015 . We estimate the potential impacts of both bilateral food trade patterns and crop water use. To do this, we utilize both an economic model of international trade and a hydrologic model of agricultural water-use.

The goal of assessing water footprints is to analyses how importing or exporting of a particular product relate to the issues of water scarcity or affect per-capita water demand of a country [13]. How a water footprint assessment looks like largely depends on the focus of interest. One can be paying attention in the water footprint of one specific process in a whole production chain, or the water footprint of a final product. Alternatively, one can be interested in the water footprint of a consumer or group of consumers or in the water footprint of a producer or whole economic sector. Finally, one can take a geographic side, looking at the total water footprint within a delineated area such as a city, province, nation, catchment or river basin. Such a total water footprint is the aggregation of the water footprints of many separate processes taking place in the area. The methodology for the calculation of one single process step forms the basis of all kinds of water footprint accounts.

The total water footprint of a single process step is the sum of the green, blue and grey components [12]:

$$
\mathrm{WF}_{\mathrm{t}}=\mathrm{WF}_{\mathrm{gr}}+\mathrm{WF}_{\mathrm{b}}+\mathrm{WF}_{\mathrm{g}}
$$

Where, $\mathrm{WF}_{\mathrm{t}}$ is the total water footprint, $\mathrm{WF}_{\mathrm{gr}}$ is green water footprint, $\mathrm{WFb}$ is blue water footprint and $\mathrm{WF}_{\mathrm{g}}$ is grey water footprint.

The green water footprint is the volume of rainwater consumed during the production process. This is particularly relevant for agricultural and forestry products, where it refers to the total rainwater evapotranspiration (from fields and plantations) plus the water incorporated into the harvested crop or wood.

The green water footprint in a process step is:

Proc, greenWF=green Water Evaporation + green Water Incorporation

The blue water footprint component of a process is:

Proc, blue $\mathrm{WF}=$ blue Water Evaporation + blue Water Incorporation + lost Return flow

The grey water footprint is computed by dividing the pollutant load ( $\mathrm{L}$, in mass/time) by the difference between the ambient water quality standard for that pollutant (the maximum acceptable concentration $\mathrm{C}_{\max }$, in mass/volume) and its natural concentration in the receiving water body $\left(\mathrm{C}_{\text {nat }}\right.$, in mass/volume):

$$
\text { WFgrey }=\frac{L}{\mathcal{C}_{\max }-C_{\text {nat }}}
$$

The critical load ( $\mathrm{L}_{\text {crit }}$, in mass/time) is the load of pollutants that will completely consume the absorption capacity of the receiving water body. It can be computed by multiplying the discharge of the water body ( $R$, in volume/time) by the difference between the highest acceptable and natural concentration:

\section{Lcrit $=\mathrm{R} * \mathrm{C}-\mathrm{c}$}

In the case that pollutants are part of an effluent discharged into a water body, the pollutant load can be calculated as the effluent volume ( $E_{f f l}$, in volume/time) multiplied by the difference between the concentration of the pollutant in the effluent $\left(\mathrm{C}_{\text {effl }}\right.$, in mass/volume $)$ and its natural concentration in the receiving water body $\left(\mathrm{C}_{\text {nat }}\right.$, in mass/volume). The grey Water Footprint can then be calculated as follows:

$$
w f_{\text {gray }}=\frac{L}{c_{\max -} c_{\text {nat }}}=\frac{E f f l^{*}\left(c_{\text {effl }-C_{\text {nat }}}\right)}{\mathcal{C}_{\max -} c_{\text {nat }}}
$$

\subsection{Estimation of the Green, Blue and Grey Water Footprint}

The agricultural and forestry sectors are major water intensive sectors, products that involve agriculture or forestry in their production system can usually have a major water footprint.

The green component in the process water footprint of growing a crop or tree (WFproc, green, $\mathrm{m}^{3} /$ ton) is calculated as the green component in crop water use (CWUgreen, $\mathrm{m}^{3} / \mathrm{ha}$ ) divided by the crop yield ( $\mathrm{Y}$, ton $/ \mathrm{ha}$ ):

$$
W F_{\text {proc.green }}=\frac{C W U_{\text {green }}}{Y}
$$

The blue component (WFproc, blue, $\mathrm{m}^{3} /$ ton) is calculated similarly:

$$
W F_{\text {proc.blue }}=\frac{C W U_{\text {blue }}}{Y}
$$

The grey component in the water footprint of growing a crop or tree (WFproc, grey, $\mathrm{m}^{3} / \mathrm{ton}$ ) is computed as the chemical application rate per hectare (AR, $\mathrm{kg} / \mathrm{ha})$ multiplied by the leaching fraction $(\alpha)$ divided by the maximum acceptable concentration $\left(\mathrm{C}_{\max }, \mathrm{kg} / \mathrm{m}^{3}\right)$ minus the natural concentration for the pollutant considered $\left(\mathrm{C}_{\text {nat }}, \mathrm{kg} / \mathrm{m}^{3}\right)$ and then divided by the crop yield ( $\mathrm{Y}$, ton/ha): 


$$
W F_{\text {proc.gray }}=\frac{\left(\alpha^{*} A R\right) /\left(\boldsymbol{c}_{\max }-\boldsymbol{c}_{\text {nat }}\right)}{Y}
$$

The green and blue components in crop water use (CWU, $\mathrm{m}^{3} / \mathrm{ha}$ ) are computed by an accumulation of daily evapotranspiration (ET, $\mathrm{mm} /$ day) over the entire growing period:

$$
\begin{aligned}
& C W U_{\text {green }}=10 * \sum_{d=1}^{\lg p} E T_{\text {green }} \\
& C W U_{\text {blue }}=10 * \sum_{d=1}^{\lg p} E T_{\text {blue }}
\end{aligned}
$$

Where, $E T_{\text {green }}$ denotes green water evapotranspiration and $E T_{\text {blue }}$ represents blue water evapotranspiration. The factor 10 is used to convert water depths in $\mathrm{mm}$ into water volumes per land surface in $\mathrm{m}^{3} / \mathrm{ha}$. The summation is done over the period from the day of planting (day 1) to the day of harvest ( $\lg p$ stands for the length of the growing period in days).

\subsection{Water Footprint of a Product}

The water footprints of products, nations or businesses are the sum of the water footprint of the processes linked with product, nation or business. The Water Footprint of a product may be computed in two different ways: with the Chainsummation method or the step-wise accumulative method.

\subsubsection{The Chain-Summation Approach}

This can only be applied in the case where a production system produces only one output product. In this circumstance, the water footprints can be related with the different process steps in the production system. It can be wholly attributed to the product that results from the system. In this direct production system, the water footprint of product $\mathrm{p}$ (volume/mass) is equal to the sum of the relevant process water footprints divided by the production:

$$
W F_{\operatorname{Prod}(p)}=\frac{\sum_{s=1}^{k} W F_{p r o c(s)}}{P_{(P)}}
$$

\subsubsection{The Step-wise Accumulative Approach}

This method is a standard way of computing the water footprint of a product based on the water footprints of the input products that were crucial in the last processing step to produce that product and the process water footprint of that processing step. The water footprint of output product $p$ is computed as:

$$
W F_{\operatorname{Pr} o d(P)}=\left\{W F_{\operatorname{Prod}(P)}+\sum_{i=1}^{y} \frac{W F_{\operatorname{prod}(i)}}{f p(p, i)}\right\} * f v(p)
$$

Wherein $\mathrm{WF}_{\text {prod }}[\mathrm{p}]$ is the water footprint (volume/mass) of output product $\mathrm{p}, \mathrm{WF}_{\text {prod }}[\mathrm{i}]$ the water footprint of input product $\mathrm{i}$ and $\mathrm{WF}_{\text {proc }}[\mathrm{p}]$ the process water footprint of the processing step that changes the y input products into the output products, expressed in water use per unit of processed product $\mathrm{p}$ (volume/mass). Parameter fp [p, i] is a so-called product fraction and parameter $\mathrm{fv}[\mathrm{p}]$ is a value fraction. The product fraction of an output product $p$ that is processed from an input product I (fp [p, i], mass/mass) is called the quantity of the output product (w [p], mass) obtained per quantity of input product (w [i], mass):

$$
f p(p, i)=\frac{w(p)}{w(i)}
$$

The value fraction of an output product $\mathrm{p}$ ( $\mathrm{fv}[\mathrm{p}]$, monetary unit/monetary unit) is the ratio of the market value of this product to the aggregated market value of all the outputs products ( $\mathrm{p}=1$ to $\mathrm{z}$ ) obtained from the input products.

$$
f v(p)=\frac{\operatorname{price}(p) * w(p)}{\sum_{p=i}^{z}[\operatorname{price}(p) * w(p)]}
$$

In which price [p] refers to the price of product $\mathrm{p}$ (monetary unit/mass). In this study, the chain summation approach was used.

\subsection{Estimation of the Virtual Water Content of Animals}

The virtual water trade related to the trade of livestock or a livestock product is computed as the trade volume of the product (ton/yr) multiplied by its virtual water content $\left(\mathrm{m}^{3} /\right.$ ton) [14]. The virtual water content of each livestock product is dependent upon the animal type from which it originates, the farming system within which the animals are grown and the physical location (climatic condition) of the production system. Hence, at first, it is necessary to assess the virtual water content of a live animal and then to distribute this over the different products produced from the animal. For simplification, it is assumed in the study that a livestock product exported from the country is fully produced within that country, supposing that animal feeds, drinks and lives based on domestic resources.

The virtual water content of an animal at the end of its life span is the total volume of water that was used to grow and process its feed, to provide its drinking water, and to clean its housing or alike. These three components of the virtual water content of a live animal are computed separately and summed up to get the total virtual water content expressed in terms of cubic meter of water per ton of live animal. The virtual water content of an animal from the feed consumed consists of two components. The first portion is the virtual water embedded inside the various feed components and the second is the mixing water that is required to prepare the feed mix. The virtual water content from feed crops depends upon the composition of feed of an animal and the total volume of feed consumed by an animal over its lifetime [14]. 
The virtual water content of an animal originating from drinking is equal to the total volume of water used for drinking water supply, calculated over the entire life span of the animal. The virtual water content of an animal originating from servicing is equal to the total volume of water used to clean the farmyard, to wash the animal and other services necessary for maintaining the environment during the entire life span of the animal. There are three components to the virtual water content (VWC) of a live animals [15]

$$
\operatorname{VWC}(\mathrm{a})=\mathrm{VWC}_{\text {feed }}(\mathrm{a})+\mathrm{VWC}_{\text {drink }}(\mathrm{a})+\mathrm{VWC}_{\text {serv }}(\mathrm{a})
$$

$\mathrm{VWC}_{\text {feed }}(\mathrm{a}), \mathrm{VWC}_{\text {drink }}$ (a) and $\mathrm{VWC}_{\text {serv }}$ (a) represent the virtual water content of animal (a) related to feed, drinking water and service water consumptions, respectively, expressed in cubic meters of water per ton of live animal.

\subsection{Water Footprint of National Consumption}

The water footprint of the consumers in a nation (WFcons, nat) has two components: the internal water footprint and the external water footprint. The internal water footprint of national consumption (WFcons, nat, int) is the use of domestic water resources to produce goods and services consumed by the national population. It is the sum of the water footprint within the nation $\left(\mathrm{WF}_{\text {area }}\right.$ nat $)$ minus the volume of virtual-water export to other nations in so far as related to the export of products produced with domestic water resources $(\mathrm{Ve}, \mathrm{d})$. The external water footprint of national consumption $\left(\mathrm{WF}_{\text {cons, nat, ext }}\right)$ is the volume of water resources used in other nations to produce goods and services consumed by the population in the nation considered. It is equal to the virtual-water import into the nation (Vi) minus the volume of virtual-water export to other nations as a result of the re-export of imported products (Ve, r). The virtualwater export (Ve) from a nation consists of exported water of domestic origin (Ve, d) and re-exported water of foreign origin (Ve, Fr). The virtual-water import into a nation will partly be consumed, thus constituting the external water footprint of national consumption ( $\mathrm{WF}_{\text {cons, }}$ nat, ext $)$, and partly be re-exported (Ve, r).

\subsection{Input Data Used}

\subsubsection{Period of Data Analysis}

Water availability fluctuates at intervals of a year and across years [16]. As a consequence of varying water availability, water demand varies as well. One should, therefore, be extremely cautious in making claims regarding a water footprint trend in time. Whatever water footprint study is undertaken, one should be explicit regarding the period of data used, because the period chosen will affect the outcome. In dry years, the blue water footprint of a crop product will be much higher than in wet years, because more irrigation water will be required. One can choose to calculate water footprints for one particular year or some specific years, in the latter case, one will combine different periods in one Crop yield (tones/ha), Crop water requirement $\left(\mathrm{m}^{3} / \mathrm{ha}\right)$, Volume of evapotranspiration per primary feed crop ( $\mathrm{m}^{3} /$ tones $)$, Cropwat model Climatic parameters from data bases Country trade of crops and livestock (tones/year), Feed volume per feed crop (tones/animal), Livestock water withdrawals $\left(\mathrm{m}^{3} / \mathrm{ha}\right)$, Virtual water content of a live animal from feed consumed $\left(\mathrm{m}^{3} /\right.$ tones $)$, Virtual water content of live animals from water withdrawals $\left(\mathrm{m}^{3} /\right.$ tone), Virtual water content of live animals $\left(\mathrm{m}^{3} /\right.$ tone) Virtual water content per product $\left(\mathrm{m}^{3} /\right.$ tone $)$ and Country virtual water trade $\left(\mathrm{m}^{3} /\right.$ year) analysis. Accordingly, the study was focused on water footprint and its share in per-capita water availability analysis of Ethiopia from 2000 to 2015 as the period of analysis.

\subsubsection{Water Resources}

Data on total renewable water resources and water withdrawals of the country was taken from the Ethiopian ministry of water, irrigation and electricity.

\subsubsection{Selected Commodities and Data Required}

Commodities of water footprints are useful for illustrating virtual water flows through trade between countries, can help the country understand supply chain risks and make informed decisions. Therefore, major imported and exported commodities are used in the analysis.

a) Export commodities

Ethiopia export different commodities to different countries in the world. The major commodities are coffee, oilseeds, pulses, spice, fruits and vegetables, flower, khat, live animals, meat and meat products, natural gum and incense, skin, textile and apparel (garment), cereals and other different commodities.

b) Import commodities

Ethiopia imports many different commodities from different countries. The imported commodities are categorized under different items such as finished products, other materials, and industrial products, but in this case, the researchers tried to identify the commodities-related to water consumption from agricultural products depending on the available data. Hence the imported commodities used in this research are broken rice, durum wheat, edible vegetable fats and oils, maize (corn) flour, other spices and wheat or muslin flour.

\subsection{Population}

The major source of population data in the country is the population census. The last census was conducted in 2007. The Inter Census Population Survey (ICPS), 2012 (1) information was also collected on population size. However, the estimates from the survey are based on the sample and have an associated sampling error. Also, the general consistency of the ICPS results with the census count of the population favors the use of census data.

Given this, the population counted in census 2007 has been used as the base population. Therefore, the total amount of the population of Ethiopia for the year of 2000 to 2015 are used in this research to know the water used in terms of percapital water demand. 


\subsubsection{Population Projection of the Country}

Ethiopia's Central Statistical Authority (CSA) has been issuing population estimates annually by age and administrative divisions beginning in the 1960s when two national sample surveys were conducted both for urban and rural. Starting in the mid- 1980's CSA based its annual projections on the 1984 population and housing census.
Current estimates (including one for the year 2008) are a continuation of annual projected estimates published by the statistical office based on the 1994 population and housing census. CSA reports projections to the year 2030. The projections are based on the assumption of moderate fertility and linear growth. Table 1 shows the urban and rural populations of the country between the years 2007 to 2015 .

Table 1. Urban and Rural Population of Ethiopia 2007 to 2015.

\begin{tabular}{|c|c|c|c|c|c|c|c|c|c|}
\hline \multicolumn{10}{|c|}{ Country Total (in Thousands) } \\
\hline \multirow{2}{*}{ Year } & \multicolumn{3}{|c|}{ Urban +Rural } & \multicolumn{3}{|l|}{ Urban } & \multicolumn{3}{|l|}{ Rural } \\
\hline & Total & Male & Female & Total & Male & Female & Total & Male & Female \\
\hline 2007 & 73,921 & 37,303 & 36,618 & 11903 & 5,916 & 5,987 & 62,018 & 31,387 & 30,631 \\
\hline 2008 & 75,719 & 38,215 & 37,504 & 12,716 & 6,353 & 6,363 & 63,003 & 31,862 & 31,141 \\
\hline 2009 & 77,651 & 39,155 & 38,496 & 13,318 & 6,649 & 6,669 & 64,333 & 32,506 & 31,827 \\
\hline 2010 & 79,634 & 40,123 & 39,511 & 13,931 & 6,950 & 6,981 & 65,704 & 33,173 & 32,530 \\
\hline 2011 & 81,668 & 41,119 & 40,549 & 14,588 & 7,274 & 7,315 & 67,080 & 33,845 & 33,235 \\
\hline 2013 & 85,838 & 43,164 & 42,673 & 15,979 & 7,960 & 8,019 & 69,859 & 35,205 & 34,654 \\
\hline 2014 & 87,952 & 44,204 & 43,748 & 16,734 & 8,332 & 8,402 & 71,218 & 35,872 & 35,346 \\
\hline 2015 & 90,074 & 45,250 & 44,825 & 17,521 & 8,721 & 8,800 & 72,553 & 36,528 & 36,025 \\
\hline
\end{tabular}

Depending on the above data, taking the year of 2007 as a reference the population data from 2000 to 2006 can be calculated.

\subsubsection{Population Forecasting}

There are so many methods for population forecasting such as arithmetic increase method, geometric increase method, incremental increase method, decrease rate method, graphical method, master plan method, and logistic curve method [9]. As a population of the country increases in the future, the present and past population data have to be taken from the census office to determine the amount of population by considering the different growth rates of the country. The projected rates for subsequent years (based on the 1994 census) are as follows:

Table 2. Population Growth rate of Ethiopia.

\begin{tabular}{ll}
\hline Year & Growth rate (\%) \\
\hline $1995-2000$ & 2.92 \\
$2000-2005$ & 2.73 \\
$2005-2010$ & 2.62 \\
$2010-2015$ & 2.44 \\
$2015-2020$ & 2.26 \\
$2020-2025$ & 2.05 \\
\hline
\end{tabular}

Source [17]

Table 2 suggests that population growth rates in Ethiopia is presumed to have peaked at $2.9 \%$ in the $1995-2009$ period after which a regime of sustained decline was observed.

\subsubsection{Geometric Increase Method}

This method of population forecasting is based on the assumption that the percent increase in population from decade to decade remains constant [18]. In this method the average percentage of growth of the last few decades is observed. The method is expressed as:

$$
p_{n}=p_{o}(1+k)^{n}
$$

Where: po=initial population $\mathrm{pn}=$ population at $\mathrm{nth}$ decade or year $\mathrm{n}=$ number of decades $\mathrm{k}=$ percentage (geometric) increase

Table 3. Total Population of the County 2000 to 2015.

\begin{tabular}{ll}
\hline Year & Total population \\
\hline 2000 & $61,350,394$ \\
2001 & $63,025,260$ \\
2002 & $64,745,850$ \\
2003 & $66,513,412$ \\
2004 & $68,329,229$ \\
2005 & $70,194,617$ \\
2006 & $72,033,716$ \\
2007 & $73,921,000$ \\
2008 & $75,719,000$ \\
2009 & $77,651,000$ \\
2010 & $79,634,000$ \\
2011 & $81,668,000$ \\
2012 & $83,742,000$ \\
2013 & $85,838,000$ \\
2014 & $87,952,000$ \\
2015 & $90,074,000$ \\
\hline
\end{tabular}

\subsubsection{Per-Capita Water Availability Calculations}

Depending on the Falkenmark (1989) indicator, the percapita water availability of the country can be calculated. It is the total annual runoff of the country divided by the population of the country in that year [19] and given by:

$$
\text { Falkenmark indicator }=\frac{\text { Annual } \text { Runoff }}{\text { Population size }}
$$

\section{Results and Discussions}

The water footprint of a product is the sum of the water footprints of the processes steps taken to produce the product (considering the selected production and supply chain). The water footprint of a consumer is the sum of the water footprints of all products consumed. It is the sum of the water footprints of its members. The water footprint of national 
consumption is the sum of the water footprints of its inhabitants. The water footprint of a business is the sum of the water footprints of the final products that the business produces. The water footprint within a geographically delineated area (e.g. a municipality, province, state, nation, catchment or river basin) is the sum of the processes of water footprints taking place in the area.

\subsection{Exported Water Foot Print}

Based on the methodology and procedures explained, the results obtained are presented in the following sections.
Depending on the input data, the exported water footprint in the form of virtual water trade from different commodities is presented. According to the results, the virtual water exported from vegetable and animal products are varying from year to year. From all commodities, the green, blue, and the grey water footprint are ranked from first to third consecutively.

The total green, blue and grey water footprints exported from vegetables, veg. products, cereals \& pulses, and animal $\&$ animal products for each year are listed in Figure 5 and Figure 6 consecutively, and summarized in Table 4 .

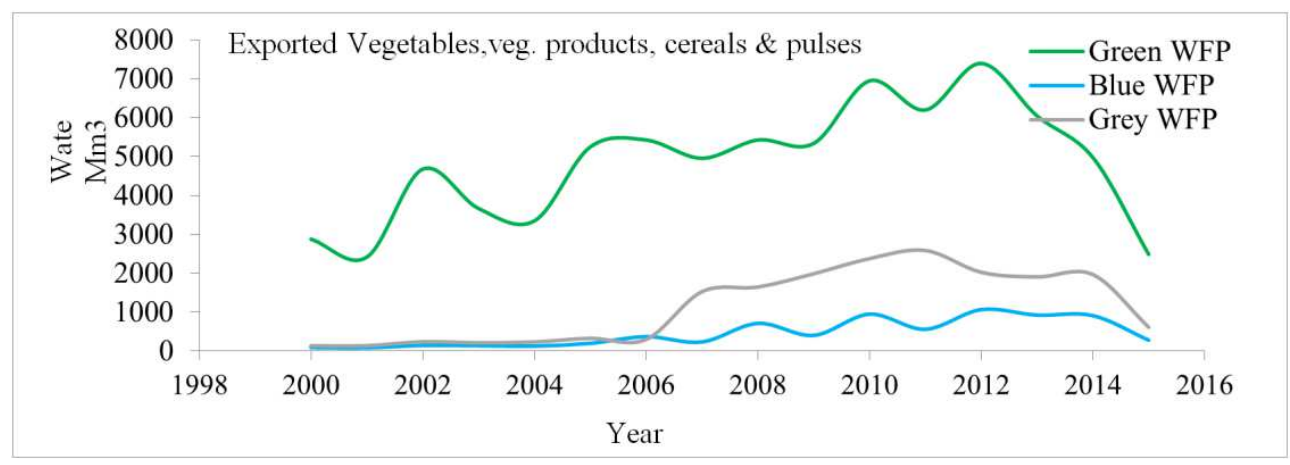

Figure 5. Exported WFP Components from Vegetables, Veg. Products, Cereals and Pulses.

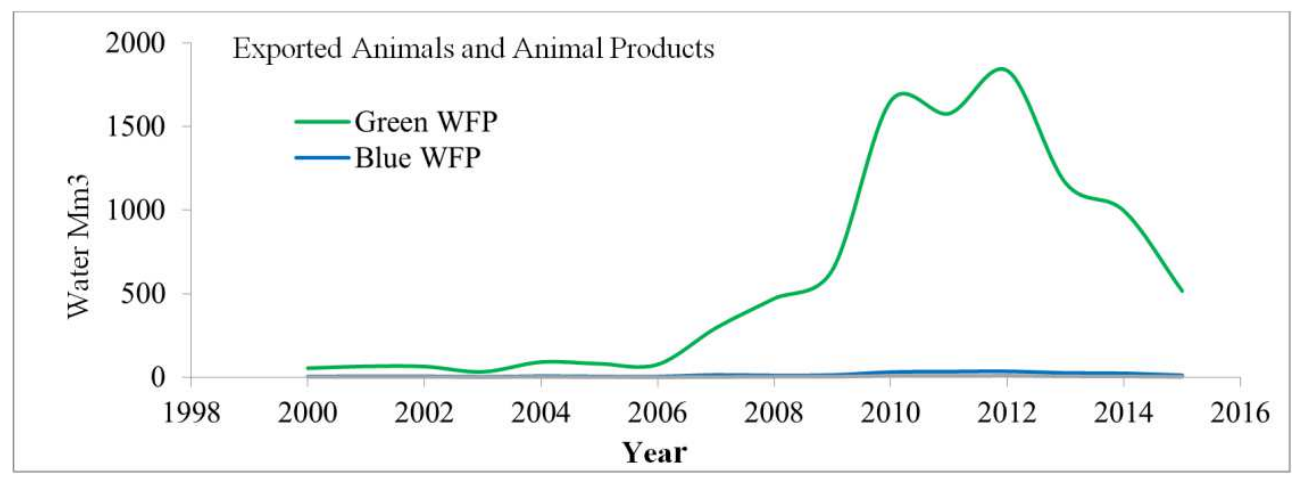

Figure 6. Exported WFP Components from Animals and Animal Products.

Table 4 presented with the exports of vegetables, vegetable products, cereals, pulse, animals and animal products, Ethiopia exported around 113 billion $\mathrm{m}^{3}$ of green, blue and grey water between 2000 and 2015.

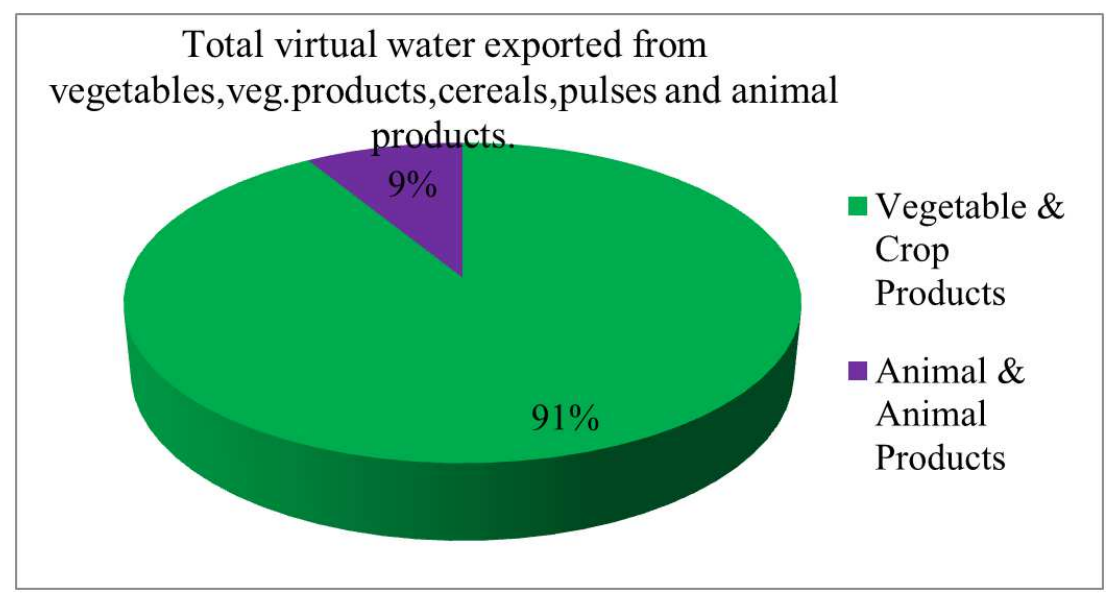

Figure 7. Total virtual water exported from vegetables and animal products by percentage. 
Table 4. Summary of exported water footprint of the country.

\begin{tabular}{|c|c|c|c|c|c|c|}
\hline \multirow{2}{*}{ year } & \multicolumn{3}{|c|}{ Vegetables, veg. products, cereals \& pulses $\left(\mathrm{Mm}^{3}\right)$} & \multicolumn{3}{|c|}{ Animal \&Anim. Products $\left(\mathrm{Mm}^{3}\right)$} \\
\hline & Green WFP & Blue WFP & Grey WFP & Green WFP & Blue WFP & Grey WFP \\
\hline 2000 & 2880 & 94.80 & 141 & 54.20 & 4.95 & 2.37 \\
\hline 2001 & 2420 & 89.40 & 142 & 65.40 & 5.97 & 2.87 \\
\hline 2002 & 4680 & 148 & 243 & 64.35 & 5.87 & 2.82 \\
\hline 2003 & 3670 & 142 & 217 & 32.60 & 2.97 & 1.43 \\
\hline 2004 & 3350 & 131 & 236 & 90.90 & 7.21 & 2.78 \\
\hline 2005 & 5250 & 203 & 332 & 81.00 & 4.83 & 0.98 \\
\hline 2007 & 4960 & 238 & 1530 & 294.83 & 13.59 & 1.46 \\
\hline 2008 & 5430 & 716 & 1650 & 470.63 & 10.95 & 3.06 \\
\hline 2009 & 5340 & 407 & 1990 & 641.98 & 13.11 & 3.30 \\
\hline 2010 & 6950 & 952 & 2380 & 1652.62 & 30.85 & 8.25 \\
\hline 2011 & 6200 & 564 & 2590 & 1577.45 & 33.55 & 7.62 \\
\hline 2012 & 7400 & 1070 & 2030 & 1834.70 & 35.04 & 9.13 \\
\hline 2013 & 6050 & 928 & 1910 & 1162.46 & 25.53 & 5.68 \\
\hline Total $\left(\mathrm{Mm}^{3}\right)$ & 77480 & 7257.2 & 18278 & 9612.363 & 233.823 & 59.922 \\
\hline Total $\left(\mathrm{Mm}^{3}\right)$ & 103015.2 & & & 9906.11 & & \\
\hline Total $\left(\mathrm{Mm}^{3}\right)$ & 112921.31 & & & & & \\
\hline
\end{tabular}

The percentages of water foot print components from exported commodities were shown in Figure 7. From the total exported commodities, vegetables, vegetable products, cereals, and pulses shared $91 \%$ and animal and animal products shared only $9 \%$. This indicated the country exported commodities were highly from vegetables, vegetable products, cereals, and pulse.
The percentages of water foot print components from exported commodities were shown in Figure 8. Around 75\%, $18 \%$ and $7 \%$ of exports of vegetables, vegetable products, cereals, and pulse were green, grey and blue water footprint, respectively. Similarly, the percentage of green, blue and grey water footprint from animal and animal products was $97 \%$, $2 \%$, and $1 \%$, respectively.

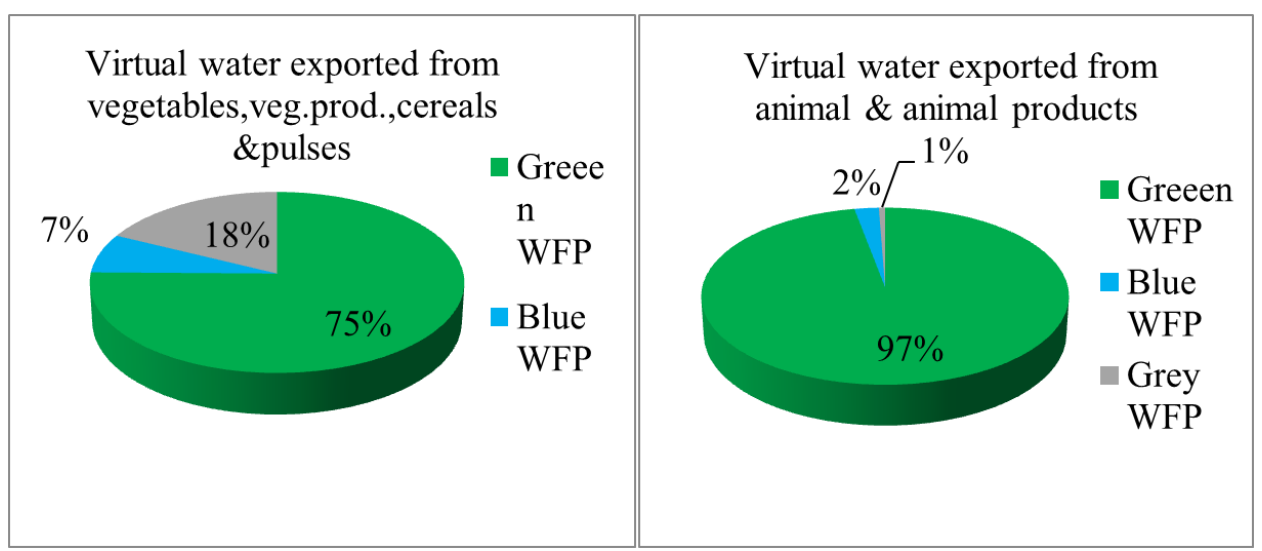

Figure 8. WFP exported from vegetable and animal products by percentages.

The total green, blue and grey water exported from vegetables, cereals and pulses were $77.48 \mathrm{Bm}^{3}, 7.257 \mathrm{Bm}^{3}$ and $18.278 \mathrm{Bm}^{3}$. Similarly, the green, blue and grey water exported from animal and animal products are $9.612 \mathrm{Bm}^{3}$, $0.234 \mathrm{Bm}^{3}$ and $0.06 \mathrm{Bm}^{3}$, respectively. The green, blue and grey water exported of country from the total exported commodities were $87.09 \mathrm{Bm}^{3}, 7.491 \mathrm{Bm}^{3}$, and $18.338 \mathrm{Bm}^{3}$, respectively. Different commodities were used to get the above values. The quantities and types of commodities were different from year to year.

From the 2000 year to 2003 year, 7 different commodities were taken, from them coffee, sesame, beans, and cotton shared higher values, consecutively. From 2000 to 2008, 53 different commodities were used from them, coffee, sesame, dried beans, live animals, dried peas and cotton ranked according to their values, consecutively. From 2009 to 2015 , 58 different commodities were used and from them, coffee, sesame seed, dried beans, dry peas, cotton, dried lentils, camels, live animals, ox, fresh chilled or frozen goat and sheep meat has shared larger values of water footprint.

\subsection{Water Foot Print Imported from Different Commodities}

The results of the water footprint calculations for imports show that Ethiopia imported around 10.9 billion $\mathrm{m}^{3}$ of virtual water from imported commodities from the years 2000 to 2015.

The total green, blue and grey water footprint from imported commodities for each are presented in Figure 9 to Figure 10 and summarized in Figure 11. 

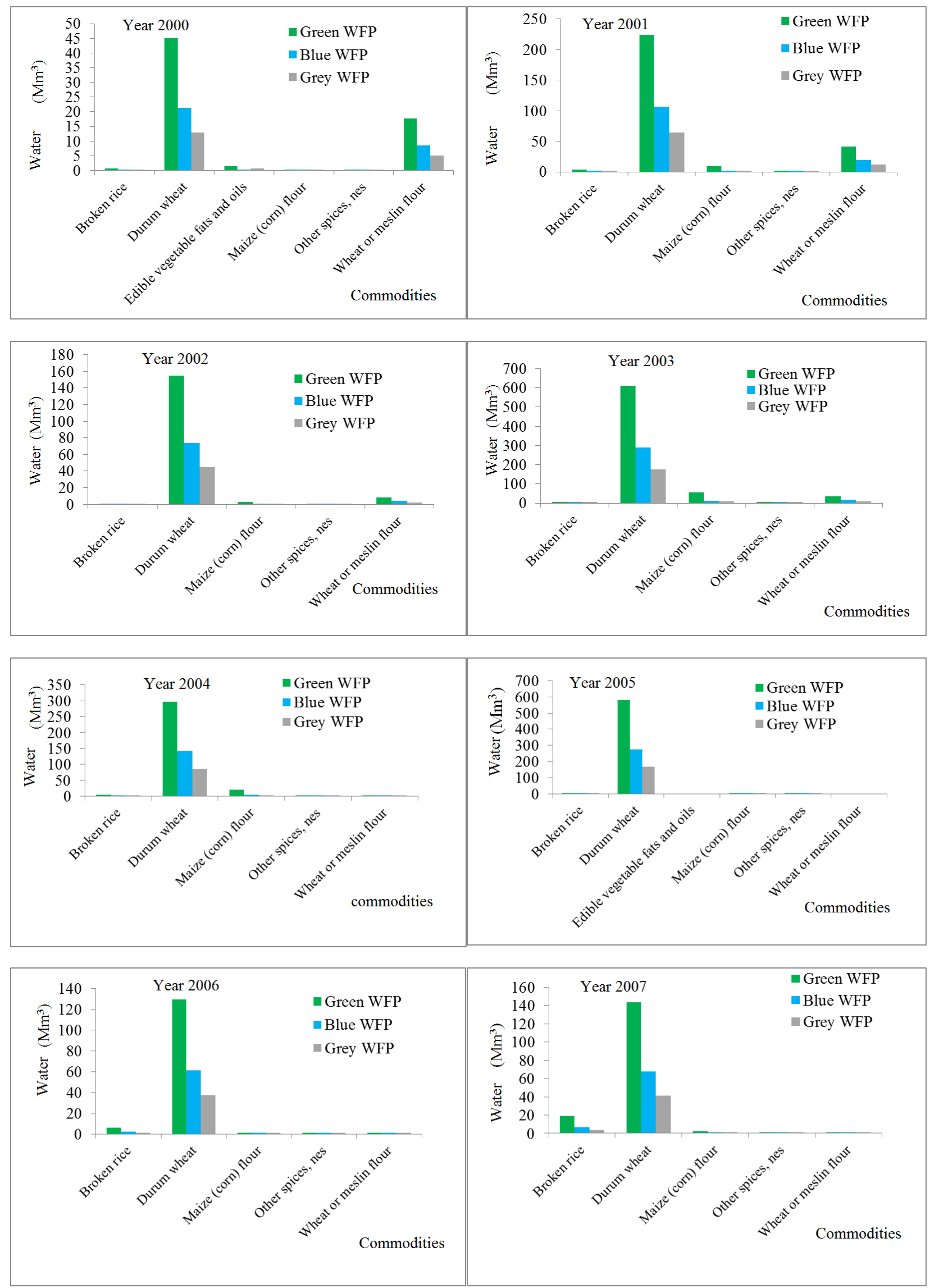

Figure 9. Imported water footprint components of the year 2000-2007. 

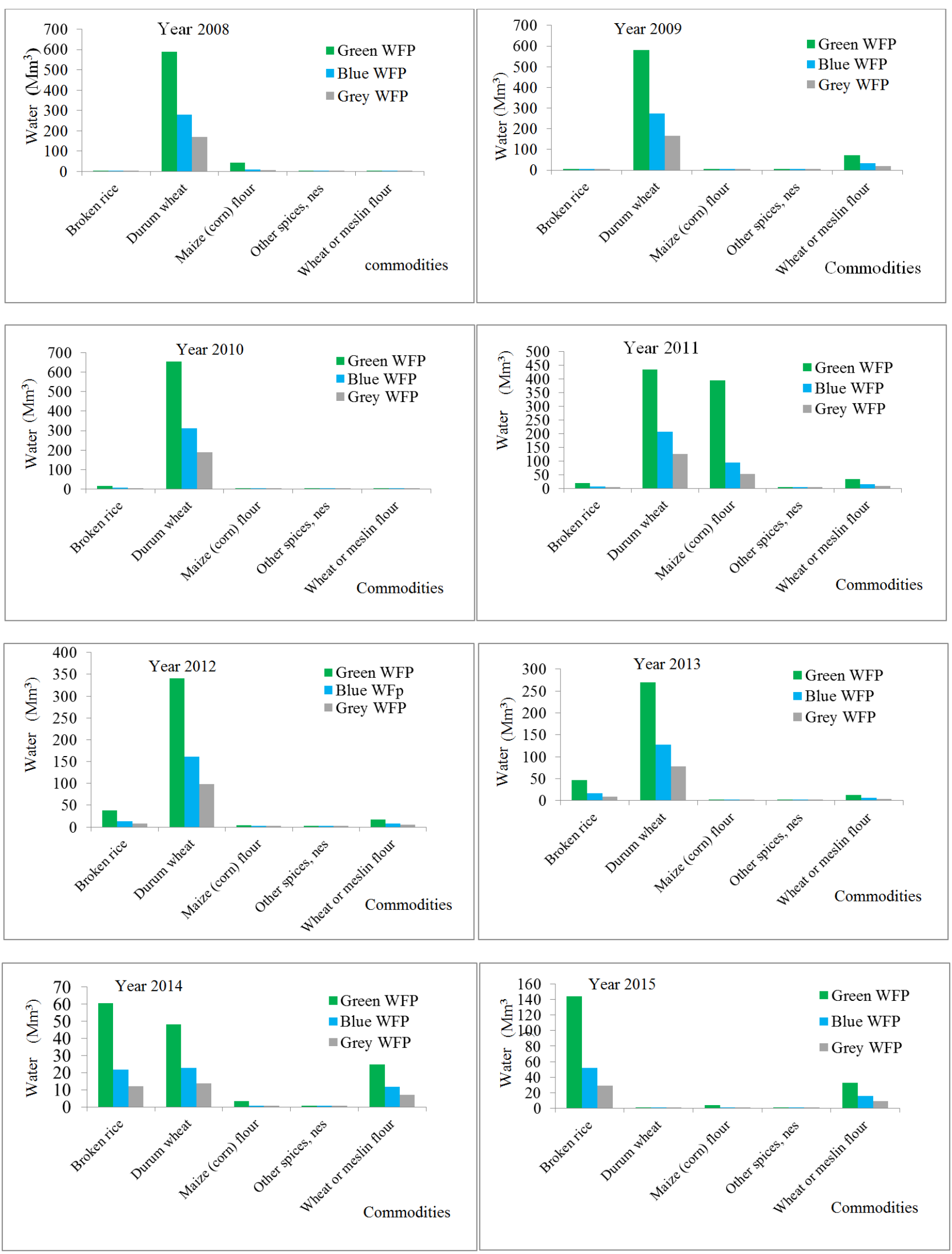

Figure 10. Imported water footprint components of the year 2008-2015.

The total components of water footprint from imported commodities were presented in Figure 11. 


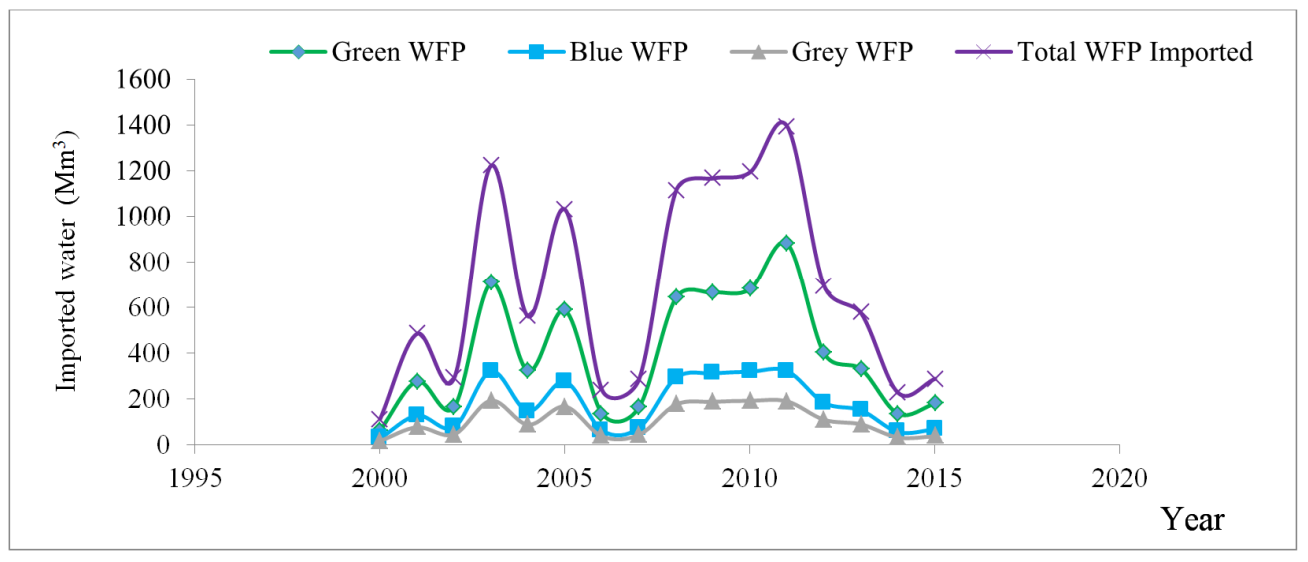

Figure 11. Summary of imported water footprint components.

The percentages of water footprint components from the imported commodities were shown in Figure 12. Around 58\% of total imports are green water footprint and $26 \%$ are blue water footprint and $16 \%$ are grey water footprint.

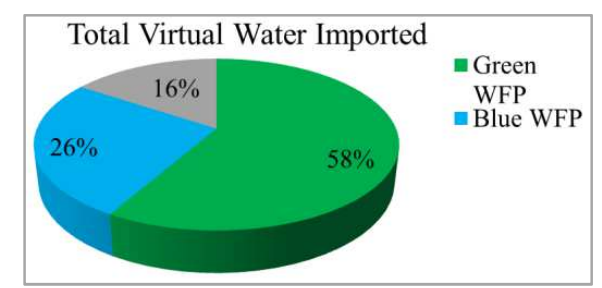

Figure 12. Total virtual water imported by percentages.

The total green, blue and grey water imported from vegetables and crop products were $6.35 \mathrm{Bm}^{3}, 2.84 \mathrm{Bm}^{3}$ and $1.71 \mathrm{Bm}^{3}$, respectively.

Different commodities were used to get the above values.
The quantities and types of commodities were different from year to year. There are 6 commodities used in the analysis and they vary from year to year, the commodities are broken rice, durum wheat, edible vegetable fats, maize (corn) flour, spiciness, and wheat or muslin flour. From 2000 to 2013 year, durum wheat was ranked first in terms of quantity imported and from 2014 to 2015 years broken rice is ranked first as a quantity of imported.

\subsection{Water Balance from Exported and Imported}

Ethiopia's virtual water trade balance for the period 20002015 is shown in Table 5. Virtual water export exceeds virtual water import, which makes Ethiopia a net virtual water exporter. The balance of water from exported and imported virtual water flow was calculated, it was computed by subtracting the imported virtual water from the exported virtual water.

Table 5. Balanced Water from Exported and Imported Commodities.

\begin{tabular}{|c|c|c|c|}
\hline Year & Total WFP Exported $\left(\mathrm{m}^{3}\right)$ & Total WFP Imported $\left(\mathrm{m}^{3}\right)$ & Water balance $\left(\mathrm{m}^{3}\right)$ \\
\hline 2000 & $3.18 \times 10^{9}$ & $1.14 \times 10^{8}$ & $3.07 \times 10^{9}$ \\
\hline 2001 & $2.73 \times 10^{9}$ & $4.86 \times 10^{8}$ & $2.24 \times 10^{9}$ \\
\hline 2002 & $5.15 \times 10^{9}$ & $2.92 \times 10^{8}$ & $4.86 \times 10^{9}$ \\
\hline 2003 & $4.07 \times 10^{9}$ & $1.22 \times 10^{9}$ & $2.85 \times 10^{9}$ \\
\hline 2004 & $3.82 \times 10^{9}$ & $5.61 \times 10^{8}$ & $3.26 \times 10^{9}$ \\
\hline 2005 & $5.87 \times 10^{9}$ & $1.03 \times 10^{9}$ & $4.84 \times 10^{9}$ \\
\hline 2006 & $6.19 \times 10^{9}$ & $2.40 \times 10^{8}$ & $5.95 \times 10^{9}$ \\
\hline 2007 & $7.04 \times 10^{9}$ & $2.88 \times 10^{8}$ & $6.75 \times 10^{9}$ \\
\hline 2008 & $8.28 \times 10^{9}$ & $1.11 \times 10^{9}$ & $7.17 \times 10^{9}$ \\
\hline 2009 & $8.39 \times 10^{9}$ & $1.17 \times 10^{9}$ & $7.22 \times 10^{9}$ \\
\hline 2010 & $1.20 \times 10^{10}$ & $1.19 \times 10^{9}$ & $1.08 \times 10^{10}$ \\
\hline 2011 & $1.10 \times 10^{10}$ & $1.40 \times 10^{9}$ & $9.60 \times 10^{9}$ \\
\hline 2012 & $1.24 \times 10^{10}$ & $6.95 \times 10^{8}$ & $1.17 \times 10^{10}$ \\
\hline 2013 & $1.01 \times 10^{10}$ & $5.75 \times 10^{8}$ & $9.53 \times 10^{9}$ \\
\hline 2014 & $8.89 \times 10^{9}$ & $2.29 \times 10^{8}$ & $8.66 \times 10^{9}$ \\
\hline 2015 & $3.92 \times 10^{9}$ & $2.89 \times 10^{8}$ & $3.63 \times 10^{9}$ \\
\hline
\end{tabular}

\subsection{Per-capita Water Availability of the Country}

Based on the water availability with in the country and the virtual water available from exported and imported, the percapita water availability was estimated. The total availability of water in the country is the addition of surface and groundwater potential of the county plus/minus the virtual water balance from exported and imported. The analyses were based on the total availability of water in the county after withdrawal divided by the total population of the county, and the per-capita for each year was presented in Table 6. 
Table 6. Per-capita water availability of the country.

\begin{tabular}{|c|c|c|c|c|c|}
\hline $\begin{array}{l}\text { year } \\
1\end{array}$ & $\begin{array}{l}\text { Withdrawal of water } \\
\text { from the country after } \\
\text { water balanced }\left(\mathrm{m}^{3}\right) 2\end{array}$ & $\begin{array}{l}\text { Available water in the } \\
\text { country (surface }+ \\
\text { groundwater) }\left(\mathrm{m}^{3}\right) 3\end{array}$ & $\begin{array}{l}\text { Available water after } \\
\text { withdrawal }\left(\mathrm{m}^{3}\right) 4(=3-2)\end{array}$ & Population 5 & $\begin{array}{l}\text { Per-capita } \\
\left(\mathrm{m}^{3} / \text { year/person }\right) 6 \\
(=4 / 5)\end{array}$ \\
\hline 2000 & $3.07 \times 10^{9}$ & $1.62 \times 10^{11}$ & $1.59 \times 10^{11}$ & $61,350,394$ & $2.59 \times 10^{3}$ \\
\hline 2001 & $2.24 \times 10^{9}$ & $1.62 \times 10^{11}$ & $1.60 \times 10^{11}$ & $63,025,260$ & $2.53 \times 10^{3}$ \\
\hline 2002 & $4.86 \times 10^{9}$ & $1.62 \times 10^{11}$ & $1.57 \times 10^{11}$ & $64,745,850$ & $2.43 \times 10^{3}$ \\
\hline 2003 & $2.85 \times 10^{9}$ & $1.62 \times 10^{11}$ & $1.59 \times 10^{11}$ & $66,513,412$ & $2.39 \times 10^{3}$ \\
\hline 2004 & $3.26 \times 10^{9}$ & $1.62 \times 10^{11}$ & $1.59 \times 10^{11}$ & $68,329,229$ & $2.32 \times 10^{3}$ \\
\hline 2005 & $4.84 \times 10^{9}$ & $1.62 \times 10^{11}$ & $1.57 \times 10^{11}$ & $70,194,617$ & $2.24 \times 10^{3}$ \\
\hline 2006 & $5.95 \times 10^{9}$ & $1.62 \times 10^{11}$ & $1.56 \times 10^{11}$ & $72,033,716$ & $2.17 \times 10^{3}$ \\
\hline 2007 & $6.75 \times 10^{9}$ & $1.62 \times 10^{11}$ & $1.55 \times 10^{11}$ & $73,921,000$ & $2.10 \times 10^{3}$ \\
\hline 2008 & $7.17 \times 10^{9}$ & $1.62 \times 10^{11}$ & $1.55 \times 10^{11}$ & $75,719,000$ & $2.04 \times 10^{3}$ \\
\hline 2009 & $7.22 \times 10^{9}$ & $1.62 \times 10^{11}$ & $1.55 \times 10^{11}$ & $77,651,000$ & $1.99 \times 10^{3}$ \\
\hline 2010 & $1.08 \times 10^{10}$ & $1.62 \times 10^{11}$ & $1.51 \times 10^{11}$ & $79,634,000$ & $1.90 \times 10^{3}$ \\
\hline 2011 & $9.60 \times 10^{9}$ & $1.62 \times 10^{11}$ & $1.52 \times 10^{11}$ & $81,668,000$ & $1.87 \times 10^{3}$ \\
\hline 2013 & $9.53 \times 10^{9}$ & $1.62 \times 10^{11}$ & $1.52 \times 10^{11}$ & $85,838,000$ & $1.78 \times 10^{3}$ \\
\hline 2014 & $8.66 \times 10^{9}$ & $1.62 \times 10^{11}$ & $1.53 \times 10^{11}$ & $87,952,000$ & $1.74 \times 10^{3}$ \\
\hline 2015 & $3.63 \times 10^{9}$ & $1.62 \times 10^{11}$ & $1.58 \times 10^{11}$ & $90,074,000$ & $1.76 \times 10^{3}$ \\
\hline
\end{tabular}

Figure 13 shows the per-capita water availability of the country. It shows that the population of the country is constantly increasing while, the per-capita water availability is decreasing.

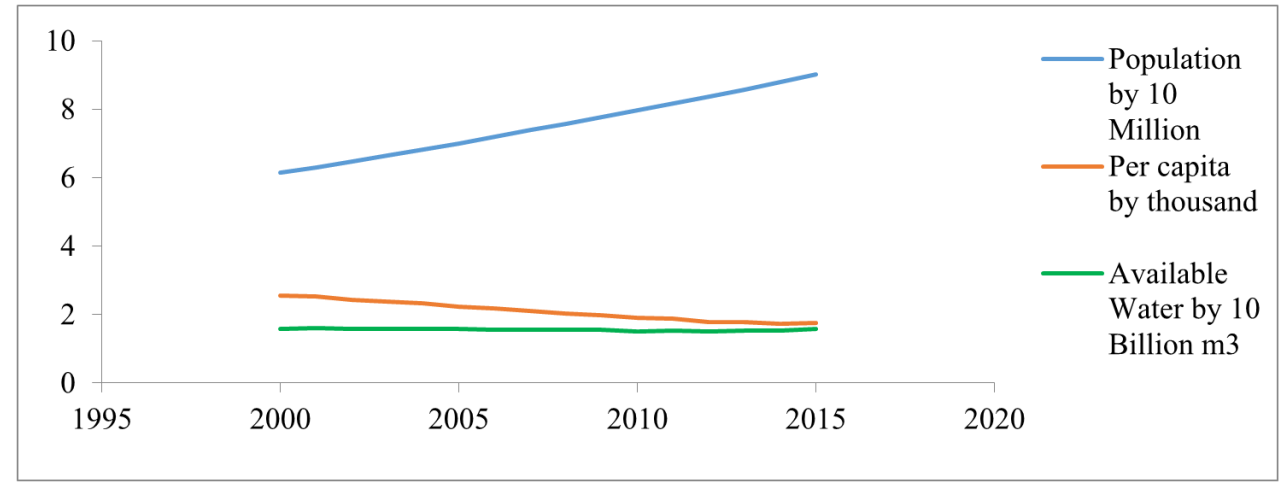

Figure 13. Per-Capita Water Availability of the Country.

As Falkenmark, indicated when per-capita water availability is greater than $1700 \mathrm{~m}^{3} / \mathrm{cap} /$ year there is no water stress in the country. Accordingly the maximum and minimum per-capita water availability in Ethiopia during the period of analysis is $2590 \mathrm{~m}^{3} /$ cap/year and $1740 \mathrm{~m}^{3} /$ cap/year respectively. These shows that there is no water stress in Ethiopia during the periods of analysis. However, the percapita water availability is decreasing from year to year. If the present population growth rate and water consumption export habit of the country continues, there will be water stress in the country after a few decades.

\section{Conclusion and Recommendations}

\subsection{Conclusions}

The paper aims to demonstrate the detailed analysis of the water footprint and its share in per-capita water availability of Ethiopia thorough assessment of the virtual water flows leaving and entering the country from different commodities. Water footprint accounts afford a broader information base than traditional water use accounts, which explain water withdrawals alone. Besides, water footprint accounts show to which extent the water is used in a certain regional state (relates to provincial consumption and to which extent to export).

The water footprint can be used to understand the interdependencies between countries from the water perspective through the export and import of goods. The analyses that was done provide an overview of water use in Ethiopia, from the perspective of the goods produced within the country, the consumption of goods, in particular, crops and animal products, by Ethiopians and whether these goods are produced domestically or imported from other countries.

The average water footprint related to the consumption of vegetables, vegetable products, cereals, pulses, animals and animal products exported from Ethiopia in the period of analysis was $113 \mathrm{Bm}^{3}$. On average Ethiopia exports a total of 7.063 billion $\mathrm{m}^{3}$ per year. The annual averages of exported green, blue and grey water were 4.843 billion $\mathrm{m}^{3}, 0.454$ billion $\mathrm{m}^{3}$, and 1.142 billion $\mathrm{m}^{3}$, respectively through its exported goods. 
But, there were large differences per year of each analysis. The water footprint exported from vegetables, vegetable products, cereals, and pulses was much higher than that of animals and animal products, and these indicated the quantity of the exported vegetables, vegetable products, cereals, and pulses are higher than that of animals and animal products. The water footprint exported between the year 2010 to 2013 are higher than the other years and accounted for $12.0 \mathrm{Bm}^{3}$, and $11.0 \mathrm{Bm}^{3}, 12.4 \mathrm{Bm}^{3}$, and $10.1 \mathrm{Bm}^{3}$, respectively. Also, the total water footprint imported by Ethiopia was $10.9 \mathrm{Bm}^{3}$. On the average Ethiopia imports 0.68 billion $\mathrm{m}^{3}$ per year. The annual imported green, blue and grey water are 0.397 billion $\mathrm{m}^{3}, 0.178$ billion $\mathrm{m}^{3}$ and 0.11 billion $\mathrm{m}^{3}$ respectively. The maximum imported virtual water was higher in the year of 2003, 2005, 2008, 2009, 2010 and 2011 which is $1.22 \mathrm{Bm}^{3}$, $1.03 \mathrm{Bm}^{3}, 1.11 \mathrm{Bm}^{3}, 1.17 \mathrm{Bm}^{3}, 1.19 \mathrm{Bm}^{3}$, and $1.40 \mathrm{Bm}^{3}$, respectively. The present result shows that imported commodities such as durum wheat, maize (corn) flour and wheat muslin flour were high.

From all exported and imported commodities, the green water footprint was ranked first, from exported vegetables, vegetable products, cereals, and pulses $75 \%$, from exported animals and animal products $97 \%$ and from imported commodities $58 \%$. This indicated the exported and imported commodities' virtual water consumptions depend on the availability of rainwater.

The biggest contribution to the water footprint per-capita is from durum wheat, wheat flour, broken rice and maize (corn) flour from all imported commodities. This is caused by the high consumption rate and the relatively high water footprint of wheat, rice and maize. on the other hand, the commodities which significantly affect the per-capita water availability of the country as a form of exported commodities are coffee, sesame seed, dried beans, dried peas, cotton, and dried lentils and from animals: camels, live bovine animals, ox, sheep meat and goat meat.

The per-capita water availability in the country is reducing progressively due to limited availability of water, growing demand for water and population increase.

The result shows that Ethiopia is a net virtual water exporter of green water, blue water, and grey water.

Understanding the water footprint of Ethiopia is important for a variety of reasons. First, Ethiopia's water resources are becoming increasingly stretched to accommodate continued population and economic growth and to restore environmental flows. Second, the water footprint provides specific information on the food systems that supply goods and services to Ethiopians, which is relevant to understanding the resource-related risks and vulnerabilities the country faces. This information is also useful to Ethiopians wishing to know the impacts of their consumption habits and other activities, thus offering new opportunities to change or reduce their environmental footprint.

\subsection{Recommendation}

Finally, the following points were recommended based on the study result:
1) From the research output, Ethiopia annually exports a virtual water volume that is more than ten times it annually imports. Detail discussion should be made on the Ethiopia's water footprint profile with ministries and departments concerned for its water resource development and management, agriculture and economic development, trade and environmental fortification on how to reduce this virtual water export

2) The current assessment of water footprints is that it focused on expressing the impact of human activities on the quantitative use of water resources. This concept virtual water should be included in the assessment of per capita water availability of Ethiopia.

3) Countries like Ethiopia can preserve their internal water resources by importing products with a high level of virtual water instead of producing them in their territory, which would mean decrease in their water stress. So the water footprint concept as a practical tool should be started in Ethiopia to analyses how consumption patterns affect water use, how future changes in consumption patterns are likely to impact on water, how countries can internalize their water footprint to reduce the pressure on the domestic water resources, and the trends on how other countries can profit from their relative abundance of water by importing water-rich commodities should be developed in Ethiopia.

4) Detail discussions should be made on economic analysis of water foot print, i.e. to develop irrigation projects by constructing hydraulic structures such like dam, weir, intake structures, canals, etc. which need huge investments to enhance the countries food security or export from these irrigation products or does it is profited to import some commodities from other countries. Therefore, all stakeholders should be involved in such issues to put the correct directions on planning and managing the water resources of the country in terms of economic analyses.

5) Research tasks need to be in required a more detailed account of the water requirements for industrial products (e.g., by considering industrial export and import commodities) and ultimately an integration of virtual water trade by accounting for the actual and potential future country pattern of production and consumption of industrial products together with the underlying green, blue and grey freshwater resources. So if somebody wants to expand this research he/she should have included the above-stated issues.

6) Water management bodies should be focused on matching local water demands with the global dimension of water while planning, allocating and policy making of water resources to know the country's water resource potential in terms of current and future availability of water. Thus, water is a key resource for future development thus all communities should be engaged by the government to save water in their daily water use. 


\section{References}

[1] World Bank (2018). (http://www.world bank.org/en/country/Ethiopia). Accessed $13^{\text {th }}$ April 2019.

[2] P. Billi (ed.), Landscapes and Landforms of Ethiopia, World Geomorphological Landscapes, DOI 10.1007/978-94-0178026-1 3, (C) Springer Science+Business Media Dordrecht 2015.

[3] Ministry of Water, Irrigation and Energy of the Government of Ethiopia (MoWIE) (2014) http://countrymeters.info/en/Ethiopia. Accessed on February $18,2019$.

[4] UN (2008). Major river basin of Ethiopia. https://www.ethiovisit.com/major-rivers-of-ethiopia/34/.

[5] Belete Berhanu, Yilma Seleshi, Assefa, M. Melesse (2014). Surface Water and Groundwater Resources of Ethiopia: Potentials and Challenges of Water Resources Development. Springer International Publishing. Switzerland. Doi https://doi.org/10.1007/978-3319-02720-36. Accessed on July 10, 2019.

[6] Reta Hailu, Degefa Tolossa \& Getnet Alemu (2018) Water institutions in the Awash basin of Ethiopia: the discrepancies between rhetoric and realities, International Journal of River Basin Management, 16: 1, 107-121, DOI: 10.1080/15715124.2017.1387126.

[7] Abate Zewdie (1995). Water Resources Development in Ethiopia: An Evaluation of Present Experience and Future Planning Concepts. Ithaca Press, Reading, UK.

[8] FAO (2016). (http://www.faostat.org/ag/agl/aglw/aquastat/countries/ethiopi a/index.stm). Accessed on March 14, 2019.

[9] Loucks D. P., van Beek E. (2017) Water Resources Planning and Management: An Overview. In: Water Resource Systems Planning and Management. Springer, Cham. https://doi.org/10.1007/978-3-319-44234-1_1.
[10] A. K. Chapagain A. Y. Hoekstra (2004). Water footprints of nations Volume 1: Value of Water Research Report Series No. 16. UNESCO-IHE Delft: The Netherlands.

[11] Hoekstra, A. Y. and Chapagain, A. K. (2008) Globalization of water: Sharing the planet's freshwater resources, Blackwell Publishing, Oxford, UK, ISBN 9781405163354.

[12] Hoekstra, A. Y. \& Chapagain, A. K. (2008). Globalization of Water, Sharing the Planet's Freshwater Resources. Blackwell Publishing, Oxford.

[13] Arjen Y. Hoekstra, Ashok K. Chapagain, Maite M. Aldaya and Mesfin M. Mekonnen (2011). The Water Footprint Assessment Manual. Setting the Global Standard. Earthscan Washington, DC.

[14] Hoekstra A. Y. (2003). Virtual water trade Proceedings of the International Expert Meeting on Virtual Water Trade: Value of Water Research Report Series No. 12, IHE Delft DA Delft: The Netherlands.

[15] Mireia Romaguera, Arjen Y. Hoekstra, Zhongbo Su, Maarten S. Krol and Mhd. Suhyb Salama. Potential of Using Remote Sensing Techniques for Global Assessment of Water Footprint of Crops. Remote Sens. 2010, 2, 1177-1196; doi: $10.3390 /$ rs2041177.

[16] Konapala, G., Mishra, A. K., Wada, Y. et al. Climate change will affect global water availability through compounding changes in seasonal precipitation and evaporation. Nat Commun 11, 3044 (2020). https://doi.org/10.1038/s41467020-16757-w.

[17] Central Statistics Agency CSA (1994). Statistical Report Population and Housing Census of Ethiopia. Statistical bulletin. Addis Ababa, Ethiopia. URI http:/www.csa.gov.et.

[18] Yitbarek Andualem Mekonnen (2018): Population Forecasting for Design of Water Supply System in Injibara Town, Amhara Region, Ethiopia: Debre Tabor University, Derbe Tabor, Ethiopia.

[19] Falkenmark, M. (1989). The massive water scarcity now threatening Africa. Why isn't it being addressed? Ambo, 18; $112-118$. 